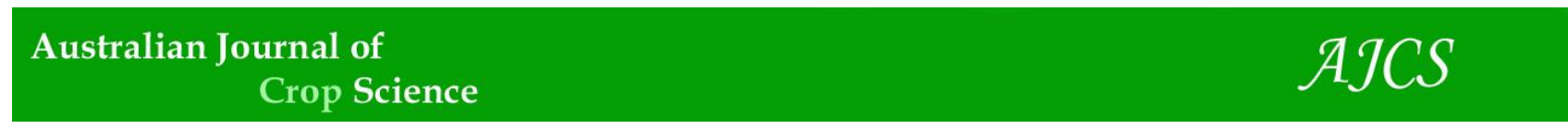

AJCS 12(03):467-471 (2018)

ISSN:1835-2707

doi: 10.21475/ajcs.18.12.03.pne949

\title{
Inheritance of resistance to dieback disease in mango (Mangifera indica)
}

\author{
Washington Carvalho Pacheco Coelho ${ }^{1}$, Carlos Antonio Fernandes Santos ${ }^{2 *}$, Diogenes da Cruz Batista ${ }^{2}$ \\ ${ }^{1}$ State University of Feira de Santana, State of Bahia, Brazil \\ ${ }^{2}$ Brazilian Agricultural Research Corporation (Embrapa Semiarid), Petrolina, State of Pernambuco, Brazil
}

*Corresponding author: carlos-fernandes.santos@embrapa.br

\begin{abstract}
The fungi Lasiodiplodia theobromae and Neofusicoccum parvum are pathogens responsible for causing dieback disease in mangoes. Studies on the inheritance of resistance to these fungal diseases in mango are quite limited. The objective of the present study was to evaluate the inheritance of resistance to dieback disease in three pseudo- $F_{2}$ progenies to assist in mango breeding programs. Young branches containing young leaves were selected, and suspension of $10^{3}$ conidia $/ \mathrm{mL}$ of $L$. theobromae or $N$. parvum was sprayed separately. After inoculation, leaves were protected in a plastic wet chamber for 48 hours. The infection was estimated by taking the branches without symptoms/total number of inoculated branches. Plants without disease symptoms in more than $90 \%$ of the branches, in three different inoculation periods, were considered as resistant. Keitt, Haden, and Espada cultivars were resistant to both fungi, while 'Tommy Atkins' was susceptible to both pathogens. Monogenic resistance, conferred by recessive alleles, was observed for $L$. theobromae for the three crossings evaluated, despite the 13:3 segregation detected for 'Keitt' $x$ 'Tommy Atkins'. For $N$. parvum, recessive resistance with 3:1 monogenic segregation was observed in the crossing 'Keitt' $x$ 'Tommy Atkins', and 9:7 epistatic segregation was reported in the crossing 'Haden' $x$ 'Tommy Atkins' and 'Espada $x$ 'Tommy Atkins'. The mono or digenic inheritance observed in the present study indicates the possibility of selection in the $F_{2}$ generation and identification of plants with double resistance to $L$. theobromae and $N$. parvum in mango trees.
\end{abstract}

Keywords: Mango; Botryosphaeriaceae; Lasiodiplodia theobromae; Neofusicoccum parvum.

Abbreviations: SFRV (São Francisco river valley); PWS (plant-without-symptoms).

Introduction

Mango (Mangifera indica L.) is native to the Southeast Asia, particularly India, and is one of the most appreciated tropical fruits in the world (Souza et al., 2002). In Brazil, despite being produced in several States, mango commercial cultivation is of great economic importance in the Northeast and Southeast regions, especially in the States of Bahia, Pernambuco, Ceará, Minas Gerais, and São Paulo (Fávero, 2008). In 2013, the export of mango accounted for US\$ 147.8 million, reaching approximately US\$ 164 million in 2014 (Anuário Brasileiro da Fruticultura, 2014; 2015). The cities of Petrolina-PE and Juazeiro-BA, located in the São Francisco river valley (SFRV) account for more than $80 \%$ of the total Brazilian export, and the European Union and the United States of America are the main consumers (IBRAF, 2011).

Mango crops are affected by several diseases caused by different pathogens, which hinders the whole production chain. The main pathogens are the fungi of the family Botryosphaeriaceae. In the producing area of SFRV, the most common fungi are Lasiodiplodia theobromae, $L$. pseudotheobromae, L. crassispora, L. egyptiaceae, $L$. hormozganensis, L. iranienses, Fusicoccum aesculi (Botryosphaeria dothidea), B. mamane, Neofusicoccum parvum, N. brasiliense, Pseudofusicoccum stromaticum, F. fabicercianum, and Neoscytalidium dimidiatum (Costa et al., 2010; Marques et al., 2013a; Marques et al., 2013b).

The $L$. theobromae occurs in about 500 plant species. The fungus is typical of tropical and subtropical regions (Punithalingam, 1980) and is easily disseminated by wind, insects, and pruning tools (Oliveira et al. 2013). According to Batista et al. (2012), at favorable conditions, the pathogen infects the plant branch, causing dieback and/or canker diseases, sometimes reaching the trunk, and even causing plant death.

Symptoms of $N$. parvum have also been reported in the region. This fungus can infect various parts of the plant, including fruits, causing severe damage and plant death (Oliveira et al. 2008; Costa et al. 2010). The most common symptoms of $N$. parvum are tip and branch dieback, wilting leaves, gummosis of branches and trunks, necrosis of floral buds and panicle, canker disease with trunk necrosis, fruit stem-end rot, and dead branches and entire trees (Slippers and Wingfield, 1998; Slippers et al. 2005).

According to Lyer and Schnell (2009), studies on the inheritance of diseases that affect mango are scarce and restricted to some observations of dominance and/or recessiveness for bacterial canker diseases and floral malformation. Arriel et al. (2016), in a pioneering study with six full-sib families, reported that resistance to Ceratocystis 
fimbriata, the causative agent of mango wilt disease, is polygenic with the prevalence of genes expressing dominance and epistasis. Studies in Florida, USA, have identified progenies originated from the crossing between 'Haden' and 'Sandersha' with no symptoms of the disease caused by the fungus Botryosphaeria ribis (anamorph: Neofusicoccum ribis), indicating that some cultivars are resistant to the pathogen (Ramos et al., 1997).

Batista et al. (2012) reported variability for resistance to $N$. parvum for the accessions Nego-não-chupa, Manga-d'água, Juazeiro VI, Juazeiro VII, and Favo-de-mel, with the lowest lesion growth daily rates. Santos Filho et al. (2002) described the genotypes Espada and Manguito as resistant to two different isolates of $L$. theobromae (=Botryodiplodia theobromae). Studies on the inheritance of the resistance of these important fungal diseases have not been described yet, and this information is fundamental to support and guide the development of cultivars resistant to these pathogens.

Mango is a highly heterozygous species, with cross pollination rate of up to $93 \%$ (Santos and Lima Neto, 2011), which can be explored for genetic studies. As stated by Banerjee et al. (2012) and Parikh et al. (2016), $F_{1}$ plants resulting from crossings between parents highly heterozygote at many loci is considered as pseudo- $F_{2}$ and not as $F_{1}$ plants. The strategy of pseudo- $F_{2}$ plants was applied by Banerjee et al. (2012), in Cornus florida; by Parikh et al. (2016), in Morus spp.; and by Arriel et al. (2016), in $M$. indica.

The objective of this study was to evaluate the inheritance of resistance to the fungi $L$. theobromae and $N$. parvum in pseudo- $\mathrm{F}_{2}$ progenies resulting from the crossing between cultivars 'Haden' $x$ 'Tommy Atkins', 'Espada' $x$ 'Tommy Atkins', and 'Keitt $x$ Tommy Atkins', aiming to assist mango breeding programs.

\section{Results}

Efficiency of inoculation procedure and resistance variability within evaluated parental mango cultivars

The procedures for the inoculations of the fungi $L$. theobromae and $N$. parvum were efficient for the appearance of dieback symptoms. The symptoms were characteristic of the diseases (Fig. 1), and pruning was carried out after each evaluation to interrupt the disease progression and to prevent the infection of older branches. Plants of the cultivars 'Keitt', 'Haden' and 'Espada' were resistant to $L$. theobromae since they presented a mean absence of symptoms of $100 \%, 100 \%$, and $95 \%$, respectively. Conversely, plants of the cultivar 'Tommy Atkins' were susceptible, as they showed a mean presence of symptoms of $74 \%$. For N. parvum, 'Keitt', 'Haden', and 'Espada' plants presented a mean absence of symptoms of $100 \%, 100 \%$ and $98 \%$, respectively. Conversely, 'Tommy Atkins' plants showed mean presence of symptoms in $66 \%$ of the branches inoculated with the suspension of this fungus.

\section{Analysis suggested mono or digenic inheritance to $L$. theobromae and $\mathrm{N}$. parvum in three mango crosses}

In the pseudo- $F_{2}$ populations, the progenies of the crossings 'Haden' $x$ 'Tommy Atkins', 'Keitt' $x$ 'Tommy Atkins', and
'Espada' x 'Tommy Atkins' presented 77, 49, and 47 susceptible plants and 29, 13, and 20 resistant plants, respectively. These results indicate monogenic Mendelian segregation of $3: 1(p<0.05)$ for $L$. theobromae in the three crossings (Table 1 ), with recessive resistance. The population 'Keitt' x 'Tommy Atkins' showed13:3 segregation hypothesis $(p<0.05)$, indicating some type of epistasis (Table 1 ).

For N. parvum, 62 and 40 susceptible plants and 42 and 27 resistant plants were observed in the crossings 'Haden' $x$ 'Tommy Atkins' and 'Espada x 'Tommy Atkins', respectively, indicating 9:7 segregation $(p<0.05)$. Conversely, the crossing 'Keitt' $x$ 'Tommy Atkins' presented 44 and 19 susceptible and resistant plants, respectively, indicating 3:1 segregation $(p<0.05)$ (Table 2). For $N$. parvum, results indicated monogenic Mendelian segregation in the crossing 'Keitt' $x$ 'Tommy Atkins', and epistatic segregation of the double recessive alleles in the crossings 'Haden' $x$ 'Tommy Atkins' and 'Espada x 'Tommy Atkins'.

For both fungi, the crossings 'Haden' $\mathrm{x}$ 'Tommy Atkins', 'Keitt' $x$ 'Tommy Atkins', and 'Espada' $x$ 'Tommy Atkins' showed 16, six and six plants with double resistance, respectively, that is, with mean absence of symptoms greater than $90 \%$ of the inoculated branches.. Plants with double resistance to $N$. parvum and $L$. theobromae, which have pre- and post-harvest significance in mango crops, have great potential for further agronomic trials, involving other traits, such as yield and fruit quality.

\section{Discussion}

Diseases are among the main factors that negatively affect or impair mango production in Brazil. The development and selection of new varieties have been the major strategy used in breeding. Queiroz and Lopes (2007) state that this strategy depends on the range of the genetic base available, which is influenced by the resources kept in germplasm banks.

The most common studies on genetic resistance in mango are related to anthracnose diseases (Bally et al., 2013), powdery mildew (Naqvi et al., 2014), mango malformation (Chakraborti and Misra, 2014), and mango wilt (Arriel et al., 2016). Works that evaluate resistance to dieback disease in mango, caused by fungi of the family Botryosphaeriaceae, are scarce.

The fungi $L$. theobromae and $N$. parvum, used in the present study, infect mango at different development stages. However, latent infection in fruits (Slippers and Wingfield, 2007) directly affects mango commercialization by causing the importer to return or discard heavily contaminated mango loads. In this sense, the selection of genotypes that show resistance to the development of the dieback disease of mango branches presumably reduce the endophytic and sequential development of these fungi from the mature branch to the inflorescence and pedicel (Johnson et al., 1992), consequently reducing stem-end rot.

Arriel et al. (2016) evaluated the inheritance of resistance to C. fimbriata in 197 mango genotypes from six families and reported that cultivars Keitt and Tommy Atkins were the most resistant, and cultivars Espada and Haden were the most susceptible to mango wilt. In the present study, cultivars Keitt, Haden, and Espada showed absence of symptoms higher than $94 \%$ in branches inoculated with $L$. theobromae, and $100 \%$ absence of symptoms in the material 
Table 1. Chi-square test ( $\chi 2$ ) for 3:1, 9:7 and 13:3 segregation for susceptible and resistant plants to Lasiodiplodia theobromae after three inoculations in three mango populations (Mangifera indica L.).

\begin{tabular}{|c|c|c|c|c|c|c|}
\hline Crossings & Inoculated plants & Susceptible plants & $\begin{array}{l}\text { Resistant } \\
\text { plants }\end{array}$ & $x^{2}$ & & \\
\hline & & & & $3: 1$ & $9: 7$ & $13: 3$ \\
\hline Haden $\times$ Tommy Atkins & 106 & 77 & 29 & $0.31^{\mathrm{NS}}$ & $11.57^{* *}$ & $5.16 * *$ \\
\hline Keitt $\times$ Tommy Atkins & 62 & 49 & 13 & $0.54^{\mathrm{NS}}$ & $13.08 * *$ & $0.20^{\mathrm{NS}}$ \\
\hline Espada $\times$ Tommy Atkins & 67 & 47 & 20 & $0.84^{\mathrm{NS}}$ & $5.26 * *$ & $5.42 * *$ \\
\hline
\end{tabular}

** and ${ }^{\mathrm{NS}}$ significant at $1 \%$ and not significant at $5 \%$ probability by the chi-square test, respectively.
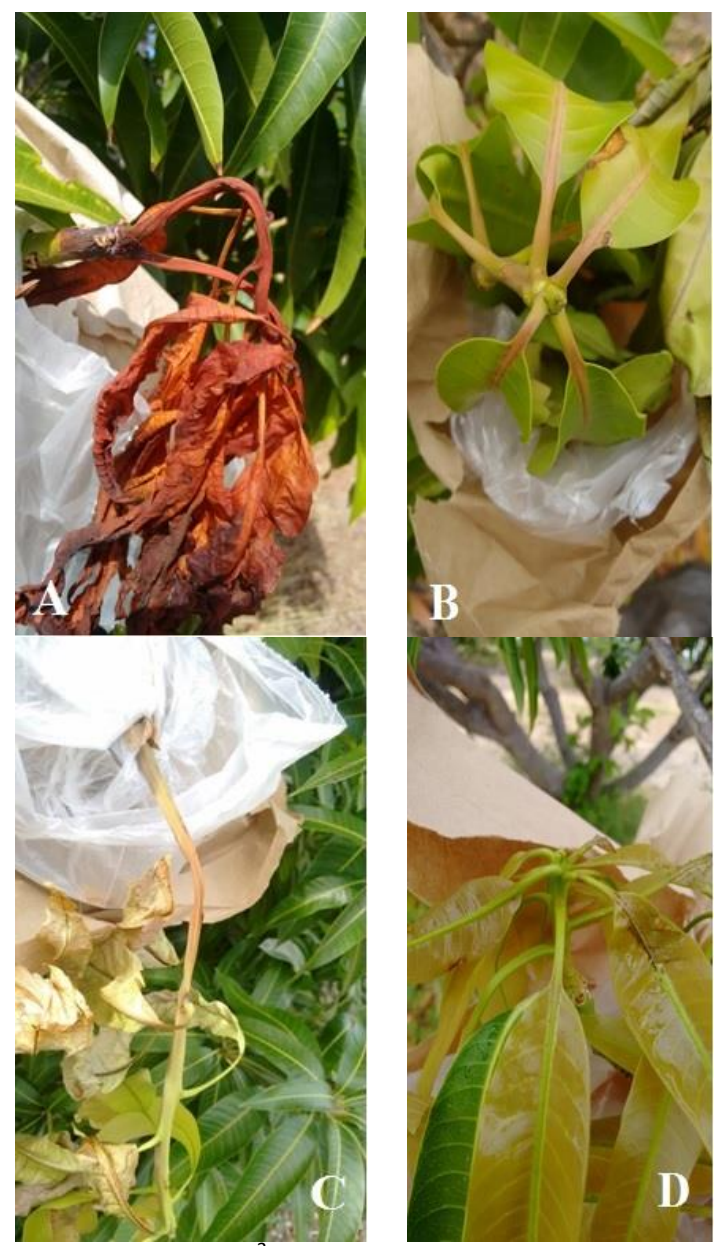

Fig 1. Symptoms of mango leaves inoculated with $10^{3}$ conidia/mL of Lasiodiplodia theobromae (A and B) and Neofusicoccum parvum ( $C$ and $D)$ : susceptible $(A$ and $C$ ) and resistant ( $B$ and $D)$.

Table 2. Chi-square test ( $\chi 2)$ for 3:1, 9:7 and 13:3 segregation for susceptible and resistant plants to Neofusicoccum parvum after three inoculations in three mango populations (Mangifera indica L.).

\begin{tabular}{|c|c|c|c|c|c|c|}
\hline \multirow[t]{2}{*}{ Crossings } & \multicolumn{6}{|c|}{ Inoculated plants Susceptible plants Resistant plants $\chi 2$} \\
\hline & & & & $3: 1$ & 9:7 & $13: 3$ \\
\hline Haden $\times$ Tommy Atkins & 104 & 62 & 42 & $13.13^{* *}$ & $0.48^{\mathrm{NS}}$ & $31.95 * *$ \\
\hline Keitt $\times$ Tommy Atkins & 63 & 44 & 19 & $0.89^{\mathrm{NS}}$ & $4.73^{* *}$ & $5.38 * *$ \\
\hline Espada $\times$ Tommy Atkins & 67 & 40 & 27 & $8.36 * *$ & $0.32^{\mathrm{NS}}$ & $20.42 * *$ \\
\hline
\end{tabular}

*** and ${ }^{\mathrm{NS}}$ significant at $1 \%$ and not significant at $5 \%$ probability by the chi-square test, respectively.

inoculated with N. parvum. Conversely, cultivar Tommy Atkins was susceptible to the diseases, with presence of symptoms of $74 \%$ and $67 \%$ for L. theobromae and $N$. parvum, respectively. Batista et al. (2012) reported that fruits of the 'Tommy Atkins' variety showed susceptibility to stem-end rot caused by N. parvum and F. aesculi.

Arriel et al. (2016) observed that the inheritance of resistance to C. fimbriata in mango is polygenic, with a prevalence of genes expressing the effects of dominance and epistasis. Bally et al. (2009) and Lyer and Schnell (2009), reported that genetic inheritance of most of the agronomic prevalence of genes expressing the effects are dominance and epistasis. For Bally et al. (2009) and Iyer and Schnell (2009), the genetic inheritance of most of the agronomic traits in mango has not yet been determined due to the long juvenile stage of the plant, high heterozygosity, 
polyembryony, cultivars incompatibility, and the use of small populations.

In this study, monogenic resistance conferred by recessive alleles was observed for $\mathrm{L}$. theobromae in the three crossings evaluated. The segregation in the population 'Keitt' $\mathrm{x}$ 'Tommy Atkins' indicated the presence of two genes of 13:3 epistatic inheritance. For Roelfs et al. (1992), some ratios are difficult to be established, such as the distinction between 3:1 and 13:1, even when evaluating large populations. For $L$. theobromae, the ratio of 3:1 is more likely to occur since no significance was observed for the three crossings evaluated. For $N$. parvum, 3:1 monogenic segregation was observed in the crossing 'Keitt' $x$ 'Tommy Atkins' and 9:7 epistatic segregation was observed in the crossings 'Haden' $x$ 'Tommy Atkins' and 'Espada x 'Tommy Atkins', indicating the possibility of different ratios in different mango crossings.

For these two important mango fungal diseases, resistant progenies can be selected in the $F_{2}$ generation, without the need for selfing for selection in subsequent generations. The mono or digenic inheritance observed in this study increases the possibility of identifying plants with double resistance to L. theobromae and N. parvum.

This is a pioneering study with mango plants, and no other works have addressed inheritance of $L$. theobromae and $N$. parvum in the species, or even in other fruit trees, which impairs comparative studies. Results of this work will assist the selection of progenies with resistance to $L$. theobromae and $N$. parvum in the crossings evaluated, and support molecular studies on mapping of resistance sources to these fungi.

\section{Materials and Methods}

\section{Plant materials}

The study was carried out at the Experimental Field of Embrapa Semiarid, in Juazeiro, BA, using the progenies of three populations of the crossings 'Haden' $x$ 'Tommy Atkins', 'Keitt' $x$ 'Tommy Atkins' and 'Espada' $x$ 'Tommy Atkins'. These populations were obtained according to the procedure described by Santos et al. (2010). Plants resulting from selfings or from crossings involving other male parents were identified by single nucleotide polymorphism markers and excluded from the genetic analyses.

\section{Production of inoculum}

Isolates of $L$. theobromae and $N$. parvum were originally obtained from the Mycology Laboratory of the Universidade Federal Rural de Pernambuco-UFRPE and used in the study. The fungi were grown for 15 days in water-agar culture medium in Petri dishes. After the development of the reproductive structures, the conidia were extracted by removing the pycnidia present in the colonies with the aid of a mortar containing distilled-sterilized water. Pycnidia were macerated with a pestle. Subsequently, the suspension was filtered, conidia were counted in a Neubauer chamber, and the suspension concentration was adjusted to $10^{3}$ conidia/mL.
Inoculation and evaluation for symptoms of $L$. theobromae and N. parvum

Inoculum suspension was sprayed on the plant leaves until runoff, without causing injury (Dhingra and Sinclair, 1995). Young branches containing young leaves were selected, and conidia suspension of $10^{3}$ conidia/mL of $L$. theobromae or $N$. parvum was applied with the aid of a hand sprayer. After inoculation, the branch was protected in a wet chamber made of plastic bags moistened with distilled-sterilized water, for 48 hours (Alfenas and Ferreira, 2007). To prevent the burning of leaves and branches by the incidence of solar radiation, the plastic bags were covered with paper bags. The development of dieback symptoms was evaluated at five days after the opening of the wet chamber. This procedure was repeated three times for both pathogens, at different periods, in each progeny of the evaluated crossings.

The method used was an adaptation of the percentage infection method developed by Valiela (1952), using the equation: plant-without-symptoms (PWS) $=$ (No. of branches without symptoms/total number of evaluated branches) $x$ 100. Plants without symptoms in more than $90 \%$ of the branches, in the mean of the three different inoculation periods, were considered as resistant to $L$. theobromae or $N$. parvum.

\section{Statistical analysis}

The adjustment between observed and expected frequencies for the hypothesis of different Mendelian and non-Mendelian ratios in the three pseudo- $F_{2}$ populations was performed using the chi-square test $(\chi 2)$ at $5 \%$ probability.

\section{Conclusion}

Monogenic resistance conferred by recessive alleles for $L$. theobromae was observed in the three crossings evaluated. For $N$. parvum, recessive resistance was detected with 3:1 monogenic segregation in the crossings 'Keitt' $x$ 'Tommy Atkins', and with 9:7 epistatic segregation in the crossings 'Haden' $\mathrm{x}$ 'Tommy Atkins' and 'Espada $\mathrm{x}$ 'Tommy Atkins'. Resistant progenies to $L$. theobromae and $N$. parvum can be selected in the $F_{2}$ generation without the need for selfing for selection in subsequent generations. The mono or digenic inheritance observed in the present study also increases the possibility of identifying plants with double resistance to these fungal diseases.

\section{References}

Alfenas AC, Ferreira FA (2007) Inoculação de fungos fitopatogênicos. Métodos em fitopatologia (Alfenas AC and Mafia RG, eds.). Universidade Federal de Viçosa, Viçosa. p. 117-138.

Anuário Brasileiro da Fruticultura (2014) Santa Cruz do Sul: Gazeta do Sul. p. $70-73$.

Anuário Brasileiro da Fruticultura (2015) Santa Cruz do Sul: Gazeta do Sul. p. $74-77$. 
Arriel DAA, Guimarães LMS, Resende MDV, Lima Neto FP, Silva DFSHS, Siqueira DL, Alfenas AC (2016) Genetic control of resistance on Mangifera indica to Ceratocystis wilt. Sci Hortic. 211:312-318.

Bally ISE, Lu P, Johnson PR (2009) Mango breeding. In: Jain SM, Priyadarshan PM (eds), Breeding Plantation Tree Crops: Tropical Species. Springer, NewYork. p. 51-82.

Bally ISE, Akem CN, Dillon NL, Grice C, Lakhesar D, Stockdale K. (2013) Screening and breeding for genetic resistance to anthracnose in mango. Acta Hortic. 992:239-244

Banerjee R, Das NK, Doss SG, Saha AK, Bajpai AK, Bindroo BB (2012) Narrow sense heritability estimates of bacterial leaf spot resistance in pseudo F2 (F1) population of mulberry (Morus spp.). Eur J Plant Pathol. 133:537-544.

Batista DC, Lima Neto FP, Barbosa JS, Amorim CC, Barbosa MAG (2012) Avaliação da resistência de 47 acessos de mangueira aos fungos Fusicoccum aesculis e Neofusicoccum parvum. Rev Bras Frutic. 34:823-831.

Chakraborti K, Misra DK (2014) Evaluation of taxa for tolerance against floral malformation in Gangetic West Bengal. Universal J Plant Sci. 2:27-30.

Costa VSO, Michereff SJ, Martins RB, Gava CAT, Mizubuti ESG, Camara MPS (2010) Species of Botryosphaeriaceae associated on mango in Brazil. Eur J Plant Pathol. 127:509519.

Dhingra OD, Sinclair JB (1995) Basic plant pathology methods, 2. ed. CRC Press, Boca Raton.

Fávero, LA (2008) A cultura da manga no São Francisco: posicionamento, limites, oportunidades e ações estratégicas. Fortaleza: Banco do Nordeste do Brasil. p. 232.

IBRAF (2015) Instituto Brasileiro de Frutas. Estatísticas. http://www.ibraf.org.br/estatisticas/est frutas.asp.

Accessed on may 2016

Iyer CPA, Schnell RJ (2009) Breeding and genetics. In: Litz RE (ed) The mango. CAB International Press, Wallingford. p. 67-96.

Johnson GI, Mead AJ, Cooke AW, Dean JR (1992) Mango stem end rot pathogens-fruit infection by endophytic colonization of the inflorescence and pedicel. Ann Appl Biol. 120:225-234.

Marques MW, Lima NB, Morais Júnior MA, Barbosa MAG, Souza BO, Michereff SJ, Phillips AJL, Câmara MPS (2013a) Species of Lasiodiplodia associated with mango in Brazil. Fungal Divers. 61:181-193.

Marques MW, Lima NB, Morais Júnior MA, Michereff SJ, Phillips AJL, Câmara MPS (2013b) Botryosphaeria, Neofusicoccum, Neoscytalidium and Pseudofusicoccum species associated with mango in Brazil. Fungal Divers. 61:195-208.

Naqvi SH, Perveen R, Manzoor S, Umar HI, Iqbal M, Liaquat F, Majid T, Irshad A (2014) Evaluation of various mango varieties against the infection dynamics of powdery mildew (Oidium mangiferae Bert.). Am J Plant Sci. 5:23722377.
Oliveira MZA, Prates Júnior P, Barbosa CJ, Assmar CC (2013) Fungo Lasiodiplodia theobramae: um problema para a agricultura baiana. Rev Bah Agric. 9:24-29.

Oliveira TAS, Oliveira SMA, Michereff SJ, Camara MPS, Costa VSO, Lins SRO (2008) Efeito do estádio de maturação, tipo de inóculo e local de inoculação na severidade da podridão peduncular em manga. Trop Plant Pathol. 33:409-414.

Parikh L, Mmbaga MT, Kodati S, Blair M, Hui D, Meru G (2016) Broad-sense heritability and genetic gain for powdery mildew resistance in multiple pseudo-F2 populations of flowering dogwoods (Cornus florida L.). Sci Hortic. 213:216-221.

Punithalingam E (1980) Plant diseases attributed to Botryodiplodia theobromae Pat, J Cramer, Vaduz. p. 123.

Queiroz MA, Lopes MA (2007) Importância dos recursos genéticos vegetais para o agronegócio. In: Nass LL (ed) Recursos Genéticos Vegetais. Embrapa Recursos Genéticos e Biotecnologia. Brasília, DF. p. 63-119.

Ramos LJ, Davenport TL, Mcmillan RT, Lara SP (1997) The resistance of mango (Mangifera indica) cultivars to tip dieback disease in Florida. Plant Dis. 81:509-514.

Roelfs AP, Singh RP, Saari EE (1992) rust diseases of wheat: concepts and methods of disease management. Cimmyt, EI Batan, Mexico. p. 65.

Santos CAF, Lima Filho JMP, Lima Neto FP (2010) Estratégias para o desenvolvimento de novas cultivares de mangueira no Semi-Árido brasileiro. Rev Bras Frutic. 32:493-497.

Santos CAF, Lima Neto FP (2011) Outcrossing rate between 'Haden' and 'Tommy Atkins' mangoes estimated using microsatellite and AFLP markers. Pesqui Agropec Bras. 46:899-904.

Santos Filho HP, Moreira WA, Tavares SCCH, Costa VSO, Matos AP, Santos CCF (2002) Doenças, monitoramento e controle. In: Genú PJC, Pinto ACQ. A Cultura da Mangueira. Brasília: Embrapa informações Tecnologicas. p. 301-352.

Slippers B, Johnson GI, Crous PW (2005) Phylogenetic and morphological reevaluation of the Botryosphaeria species causing diseases of Mangifera indica. Mycologia. 97:99 110.

Slippers B, Wingfield MJ (1998) Botryosphaeriaceae as endophytes and latent pathogens of woody plants: diversity, ecology and impact. Fungal Biol Rev. 21:601-610.

Slippers B, Wingfield MJ (2007) Botryosphaeriaceae as endophytes and latent pathogens of woody plants: diversity, ecology and impact. Fungal Biol Ver. 21:90-106.

Souza JS, Almeida CO, Araujo JLP (2002) Cardoso CEL. Aspectos socioeconômicos. In: Genu PJC, Pinto ACQ A Cultura da Mangueira. Brasília: Embrapa informação Tecnológica. p. 21-29.

Valiela MF (1952) Introductión a la fitopatologia, 2. ed. Talleres Gráficos “Gadda”, Buenos Aries. 